\title{
Intact Choriogonadotropin Measurement
}

National Cancer Institute

\section{Source}

National Cancer Institute. Intact Choriogonadotropin Measurement. NCI Thesaurus.

Code C147361.

The determination of the amount of intact choriogonadotropin present in a sample. 